\title{
Water use and its perception in the hotel industry in the Iberian Peninsula
}

\author{
Elena Terradillos ${ }^{1[0000-0001-5553-5406]}$ and Aldina Soares 1[0000-0003-1230-0265] \\ ${ }^{1}$ Instituto Politécnico de Setúbal - Escola Superior de Tecnologia de Setúbal \\ Campus do IPS, Estefanilha, 2914-508, Portugal \\ aldina.soaresdestsetubal.ips.pt
}

\begin{abstract}
Tourism industry is one of the fastest growing in recent years, before the pandemic, and is a well-known industry with excessive consumption of water. Climate change together with the abusive use of water resources change the hydrological cycle, thus causing water supply problems. Consequently, tourism companies must undertake actions to change the direction based on a more structured knowledge and vision.

This work is based on the study of water consumption in the various activities of tourist accommodations in the Iberian Peninsula. It aims to compare the perception of their consumption against the published reference values, as well as to apply measures to reduce water consumption.

The applied methodology is based on an initial bibliographic research of the state of the art, reference values for consumption, and the influencing factors in tourist accommodation. Following, the perception of consumption is assessed through an online survey targeting Portuguese and Spanish hoteliers. The survey was conducted in the first months of 2020 and 174 responses were obtained, 101 from Spain and 73 from Portugal.

The results show that the surveyed hoteliers do not have the perception of water consumption, since in general they do not make measurements, are unaware of the consumption of each sector within the hotel and mostly refer to consumption below the reference values. Regarding the measures that have already been implemented to reduce water consumption, they represent measures of lower cost and easier application and that do not require major changes.
\end{abstract}

Keywords: Tourist Accommodation, Water Use, Consumption Perception.

\section{Introduction}

Tourism is an industry that induces transversal development and the evolution of society. Until the pandemic COVID, tourism was one of the sectors that had grown the most in the world. It offers the most investment opportunities also in the Iberian Peninsula, which is the territory where this work is applied. According to the Turismo de Portugal Homepage it has had a great evolution in this area with an increase till 2019, for example, in Portugal the revenues increase from 2018 to 2019 has grown $8.1 \%$ [1]. Spain and Portugal together have had a great growth in tourism, it was ex- 
ponential between 2014 and 2017 (21\%) and from 2017 to 2019 it grew more moderately increasing about $2 \%$ [2-3].

Tourism is a modifier for the economic, social, cultural, and environmental structure of each region, country. The modifying element can be positive, causing the areas close to the touristic development to develop, and in a negative way, inflation of the cost of living in the area, economy dependent on tourism, and the most negative side is the impact it has on the consumption of natural resources on the zone [4].

The excessive consumption of natural resources, such as fresh water, causes a decrease in natural water reserves and consequently has an impact on the local flora and fauna. The negative effect, together with climate change, makes it increasingly problematic to obtain water for human consumption. Long periods of the year with extreme scarcity together with the irregular and reduced rainfall: that will be the climatic situation in the Iberian Peninsula. Thus, it is increasingly important to have water resource management policies to adapt tourism enterprises to climate change [4].

Climatic data show that the climate in the Iberian Peninsula in recent years has been very unstable [5-7]. In this territory, precipitation in recent years has been quite irregular, and the asymmetry that exists between North and South in relation to precipitation shows two very different realities in relation to the impact that climate change is making today. The Iberian Peninsula has a very humid North and an increasingly dry South [4]. Climate change models anticipate heat waves and worsening drought in the south. According to a study carried out by the Portuguese Environment Agency, between 1931 and 2000 the climate in Portugal is predominantly colder than in the remaining years, from 2000 to 2019 there is a generalized increase in temperatures. In Spain, according to AEMET between 1971 and 2018, it is observed that the temperature and precipitation in this country is very fickle, highlighting the problem of climate change that is felt in the Iberian Peninsula. Regarding the Spanish territory, the temperature has increased approximately $1.5^{\circ} \mathrm{C}$ over the last 53 years, in relation to the precipitation which has been very uneven and inconsistent [7].

\section{Water use in hotels}

As already mentioned, tourism is a modifying element of the area surrounding it. With high tourist demand, the surrounding area will also have a great responsibility for accommodation. And to satisfy the needs of each guest, there is a problem: excessive water consumption. The excessive use of water resources, namely fresh water, can have negative effects on time and space beyond the place and the moment in which the action takes place, however, climate changes such as the increase in water stress in the area where the tourism enterprise operates will, sooner or later, present consequences.

There are many reasons why the hotel industry should take a different approach to water use. This is because water consumption in hotels is generally carried in large volume to cover the need for a wide variety of facilities and leisure services/attractions. Water consumption is influenced by a set of basic consumptions that are associated with: location, climate, category / luxury, hotel size, number of beds, year of construction / renovation, swimming pools, SPA, water parks, golf, among others. Another reason why water consumption in hotels is excessive is due to the 
behaviour of guests. This increase is caused by a change in the behaviour when compared with what is common practice at home, since it is adopted a "pleasure approach" in daily routines, such as bath time [8-10].

\subsection{Reference values}

For the evaluation of the performance of a hotel unit, reference values must be considered, which can be based on an evaluation system, with objectives, criteria, and metrics. In order to be able to compare water consumption in the various areas of the tourist accommodation, water consumption must be presented per guest and per night or per room. Additionally, it must be taken into account that the use of water varies throughout the year, due to occupancy rate and climate factors, and basic consumption. Although trying to have reference values, water consumption in a hotel can vary a lot depending also on the type and category of the hotel and its location. In a study carried out in 21 countries by Almeida, Loureiro, Poças \& David [11], it was found that water consumption varies between 40 and 2500 liters per overnight guest. In European countries water consumption can vary between 200 to 1000 liters for each guest depending on the type, size and category of the tourist resort, in Asian countries the consumption is about 900 liters for each guest [11-14].

For the case study, analysis has considered the listed values as well as the values shown in Figure 1 and chosen the lowest value of 439 liters/guest/night, as the reference indicator.

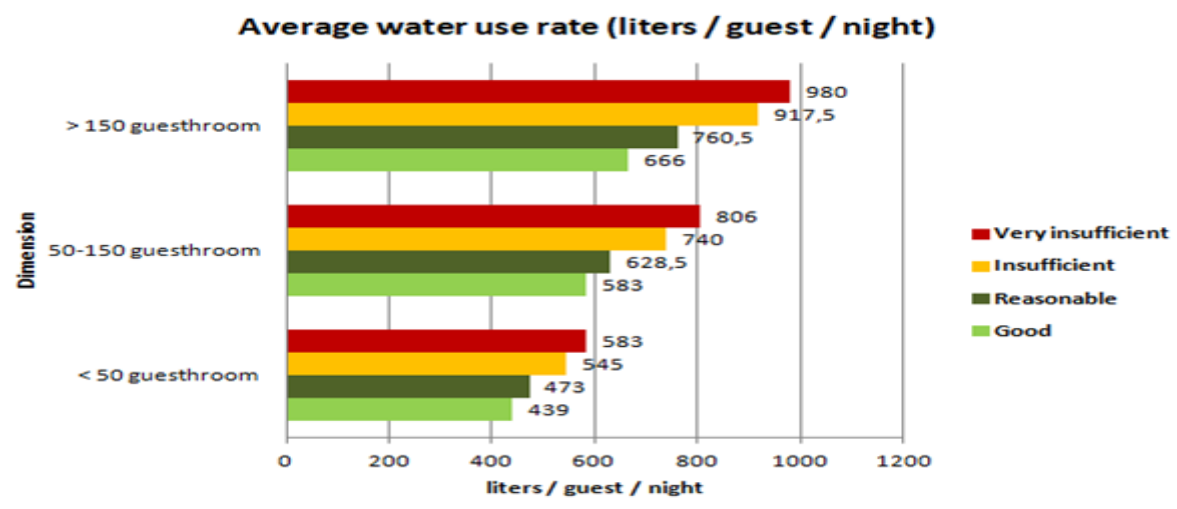

Fig. 1. Efficiency in the use of water for accommodation of different dimensions. The scale ranges from very low water use efficiency (Very Insufficient) to good efficiency (Good), measured by the indicator Average Water Use Rate in liters/guest/night (adapted from [11]).

In order to have water consumption per guest, a performance indicator must be used. The most appropriate indicator for the efficient use of water in tourist developments is the consumption of water that each guest spends per night. Thus, consump- 
tion must be calculated using the following formula, used by several researchers [1114]:

$$
C_{\text {guest per night }}=\frac{\left(C_{\text {Total }} * 1000\right)}{N_{\text {Nights for each guest }}}
$$

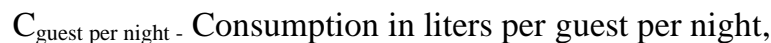

$\mathrm{C}_{\text {Total }}$ - total consumption in $\mathrm{m}^{3}$ for the calculation period (water meter),

$\mathrm{N}_{\text {nights for each guest }}$-Total amount of overnight stays, in the same calculation period.

\section{Developments in methods and techniques to reduce water consumption in hotels}

The answer to climate change involves adapting the accommodation units to climate change, that is, by adapting the accessories/equipment of the water distribution system with more appropriate elements and implementing more appropriate measures to increase efficiency as well as its management. In this way, an action is defined that has the direct result of a more efficient use of water, by reducing both losses and the amount of water for each use.

The most relevant measures for the adequacy of tourist accommodations are as follows [11-14]:

- Measures at the level of supply systems that are aimed at reducing water consumption in supply systems (example: by reducing pressures on the supply system and using treated urban wastewater). However, this application is the responsibility of the entity that manages the public supply system with coordination with consumers. Flow measurement at various points of use can be a way to identify and evaluate potential zones that can be readjusted.

- Measures at the level of building systems and collective installations within these measures include the reduction of pressure in the building supply system, the thermal insulation of the hot water distribution system, the use or reuse of rainwater and gray water and the reduction of water losses in the system with the help of maintenance and monitoring actions of the supply system.

- Measures at the level of uses like residential ones and specific to collective use facilities are understood to be the uses associated with the personal hygiene of guests, sanitary facilities, washing of clothes and dishes, as well as heating and air-cooling systems. It aims to promote proper use by users; reduce water losses and waste. The most relevant measures are the following: adaptation or replacement: cisterns, showers, taps, washing machine, dishwasher, urinals, air conditioning system.

- Measures at the level of outdoor uses include watering gardens, green spaces in general, washing yards, accesses, filling swimming pools, lakes and water uses for ornamental purposes and washing vehicles. The most relevant 
measures are the following: adaptation or replacement irrigation system, outdoor washing system, pool supply system. Introduction of systems such as the capture of rainwater for the use of tasks that do not require drinking water, use of grey water.

- Awareness and information measures, these must be developed internally for the organization's employees and for the users of the accommodation unit. In relation to employees, an action plan for the efficient use of water must be defined, through communication and training. For the remaining users, it is necessary to inform and reinforce this information through notices, signs, and awareness actions, both by employees and by the environment where they are.

\section{Case study}

\subsection{Methodology}

To achieve the research objective, an online survey was conducted to Portuguese and Spanish hoteliers. The survey included three parts: first part is about accommodation unit general questions, such as the type and category, occupancy rate, if it has a garden, and if the hotel has golf. In the second part of the survey, the questions are about water consumption total and in some areas, if it was measured or there is a perception of the consumption, the origin of the water used, and especial questions for gardens and maintain green spaces. The third part refers to questions about the measures already implemented and those that intend to be implemented in the accommodation in the future to reduce water consumption.

The survey took place in the first months of 2020. The GoogleForms platform was used to carry out the survey, in which 850 inquiries were sent, 500 to tourism enterprises in Spain and 350 in Portugal. The data were processed individually and subsequently compared between the two countries.

\subsection{Survey results}

A total of 174 inquiries answers were obtained, that is, a response rate of about $21 \%$, 101 were Spanish and 73 Portuguese.

Regarding the type and category of tourist accommodations (hotel stars or LA): 1star $(9 \%), 2$-star (14\%), 3-star $(22 \%)$, 4-star $(26 \%)$ and 5-star $(6 \%)$ and local accommodation-LA (7\%). In both countries regarding the tourist resorts that responded to the survey, about $68 \%$ have less than 50 rooms, $20 \%$ have between 50 and 150 rooms and $13 \%$ have more than 150 rooms.

\subsection{Results analysis}

In relation to annual water consumption, in Portugal around $30 \%$ consume less than $5000 \mathrm{~m}^{3}$ per year and $25 \%$ have no knowledge about the total amount of annual consumption. On the other hand, in Spain, the same is observed, about 36\% of tourist developments consume less than $5000 \mathrm{~m}^{3}$ per year, and $23 \%$ cannot estimate annual water consumption. Regarding the perception of annual total consumption, it is noted 
that most of the hoteliers, of both countries, have difficulty in knowing or even estimating them.

Relating to the indicator of consumption per guest/night, comparing to the reference value about $59 \%$ consume less than 439 liters/guest/night and about $23 \%$ do not know how to estimate this consumption. When analyzing consumption data per guest per stay, accounting for all consumptions related to your stay (restaurant, pool, golf, among other activities / amenities), it appears that the answer is similar when not counting all water consumption.

For green spaces (garden, golf), the 174 tourist accommodations that participated in the survey, about $51 \%$ have green spaces. In relation to water consumption in this sector, about $33 \%$ do not know how much water is necessary to maintain these areas. Regarding the origin of the water for irrigation, there are differences between the tourism projects in both countries. In Portugal, about $41 \%$ use water from an own borehole, and 35\% from the mains water supply, while in Spain it was noted that, on the contrary, about $56 \%$ of tourist developments use water from the mains water supply for irrigation and only $20 \%$ from an own borehole. This difference can originate from several causes, such as the price of mains water, or from legal difficulties in opening own boreholes, or even the access to water reserves in the region, or other causes; but no data were collected in the survey to conclude why this difference between countries.

Regarding the actions to reduce water consumption and through the literature it is possible to find several technical measures. One of these actions is to measure the water consumption by zones. In view of this, only about $30 \%$ of respondents have counters by zones and around $70 \%$ do not have. Concerning the measures implemented to reduce water consumption, there is consensus on the responses in both countries. The most used measures are signs, warnings (save water, etc.), use of washing machines always at maximum capacity, use of the right dosage both for washing clothes and other washing/cleaning tasks, double flush toilet discharge. In relation to the future measures to be implemented to reduce water consumption, there were some responses that indicate "they have no intention", and the remaining responses were those previously mentioned, signs, warnings and among others.

\section{Conclusions}

The purpose of this research was to study water consumption in the various activities most common in Iberian Peninsula tourist accommodations, comparing these values with published reference values and also identify whether the techniques and good practices for saving water are known and whether they are applied. In order to obtain the data, a survey was carried out based on interviews with reference tourist resorts, and an analysis of the cases in the literature.

About water consumption, it appears that about $59 \%$ of hotels in the studied region say they consume relatively little water, noting that the consumption to accommodate one guest per night is less than the chosen reference value of 439 liters/guest/night, and about $23 \%$ cannot estimate water consumption. This leads us to deduce that with 
great probability the values that answered are not the reality, or the greatest part does not know and wanted to give a good environmental image.

Regarding the techniques and measures they already have or intend to use to combat the excessive use of water, it appears that the hoteliers both in Portugal and Spain use the most economical and easy measures to implement. The most used measures are: "Double flush toilet", "Warnings (save water, don't scrub your teeth with running water, use the flush for each function, reuse towels and bedding when possible, give preference to the shower, etc.)", "Washing machines are always used to their maximum capacity", \% "Use of correct dosage of detergents for washing clothes", "Low flow regulators", "Use of correct dosage of detergents for cleaning". Still analyzing this important issue for the reduction of water consumption, it is noted that when questioned by the measures they wish to implement in the future there is very little desire to implement more expensive measures that could help to overcome this problem of excessive water consumption as they are more effective to place merely a sign or a warning.

\section{References}

1. Turismo de Portugal Homepage,

http://business.turismodeportugal.pt/pt/Conhecer/Apresentacao/Desempenho_Turistico/Pa ginas/default.aspx, last accessed 2020/06/01.

2. INE Instituto Nacional de Estadística - Hostelería y Turismo (2019). https://www.ine.es/dyngs/INEbase/es/categoria.htm?c=Estadistica_P\&cid=125473557686 3 , last accessed 2020/06/15.

3. Figuerola, M.: Evolución del turismo en España durante el año 2018, España, (2019).

4. Ferreira, P.: Alterações climáticas e desenvolvimento, Projeto: coerência.pt - O eixo do Desenvolvimento, Lisboa, novembro, (2017).

5. Alfonso, C., Estévez, R.: Emergencia climática en España, Observatorio Sostenibilidad, diciembre, (2019).

6. Guerra, M., Ribeiro, R., Rodrigues, S.: Relatório do estado do ambiente, Agência Portuguesa do Ambiente, junho, (2019).

7. AEMET: Meteorología - Informe anual 2018, AEMET, Gobierno de España - Ministerio para la Transición Ecológica Madrid, (2018).

8. Torres-Bagur, M., Ribas, A., Vila-Subirós, J.: Incentives and barriers to water-saving measures in hotels in the mediterranean: A case study of the Muga River Basin (Girona, Spain), University of Girona, June, (2019).

9. Rodrigues, G.: Análise técnico-econômica de um sistema de aproveitamento de água pluvial num empreendimento do setor hoteleiro em Delmiro Gouveia, Relatório final - Bacharel em Engenharia Civil, Universidade Federal de Alagoas, Engenharia Civil, Delmiro Gouveia-AL, (2018). 
10 Tróia Resort: Declaração ambiental 2018, EMAS \& SGS, $2^{a}$ Atualização, https://emas.apambiente.pt/sites/default/files/files/emas/declaracoes/Declara\%C3\%A7\%C 3\%A3oAmbiental_2018_vf.pdf, last accessed 2020/05/21

11 Almeida, M., Loureiro, D., Poças, A., David, L.: Água em empreendimentos turísticos Estado da arte, AdaPTAC:T: LNEC; IPMA, Junho, (2015).

12 Pinto, A.:Estado da arte: Aspetos gerais e identificação de indicadores, LNEC e IPMA,

.] (2015).

13 Amazona, I.: A solução que cai do céu: revisão das normas para a captação de água pluviais e proposição para o setor hoteleiro no Brasil, Revista Direito Ambiental e sociedade, 6, 239-263, Brasil, Julho, (2016).

14 Styles, D., Schonberger, H., Martos, J.: Best Environmental Management Practice in the Tourism Sector, Institute for Prospective Technological Studies - European Commission, ISBN: 978-92-79-30895-6 (pdf), (2013). 